\title{
“Jungle Quest” Edukasi Pengetahuan Umum Lima Binatang Langka Indonesia Dalam Permainan Kartu
}

\author{
Hizkia Kurniawijaya Hanz, \\ Samuel Gandang Gunanto ${ }^{2}$, Pandan Pareanom ${ }^{3}$ \\ Program Studi Animasi, ISI Yogyakarta \\ Email: heskihanz@gmail.com ${ }^{1}$, gandang6@gmail.com²,pianisganteng@yahoo.com³
}

\begin{abstract}
Abstrak
Di era permainan digital ini, cardgame (permainan kartu) cukup sulit untuk menemukan pasar, dikarenakan usaha yang harus dikeluarkan, dan biaya produksi yang tidak sedikit. Dibandingkan dengan game digital yang hanya butuh diunduh dari apps store dan dapat dimainkan dimana saja tanpa mengeluarkan uang banyak bahkan gratis.

Menurut data komunitas boardgame di website boardgame.id, jumlah antusias pemain boardgame di indonesia tahun 2017 ini semakin bertambah karena semakin banyak developer-developer indie yang mulai membuat boardgame dengan ide ide kreatif dan menarik, sehingga menarik perhatian para peminat boardgame untuk mencoba dan bermain

Berdasarkan data tersebut penulis mengajukan rancangan penciptaan permainan kartu yang bisa dimainkan oleh orang-orang kalangan tertentu dengan tema edukasi informasi hewan langka Indonesia. Jungle Quest bertujuan antara lain memeberi informasi mengenai pengetahuan umum lima hewan langka Indonesia, sekaligus melatih ketangkasan ingatan pemain.
\end{abstract}

Kata kunci : Cardgame, Game, Jungle Quest

\begin{abstract}
In this era of digital games, card games are quite difficult to find markets, because they have issue, and the production costs are not small. Compared to digital games that only need to be downloaded from the store application and can be played anywhere without spending a lot of money even free.

According to the boardgame community data on the boardgame.id website, the number of enthusiastic boardgame players in Indonesia in 2017 is increasing because more and more indie developers are starting to create board games with interesting and creative ideas, which can attract board game enthusiasts to try and play

Based on these data, the author plans a card game that can be played by certain people with the education theme of Indonesian rare animal information. Searching for Forests, among others, provides information about the general knowledge of five rare Indonesian animals, while training players' dexterity.
\end{abstract}

Keywords: Cardgame, Game, Jungle Quest 


\section{PENDAHULUAN}

\section{Latar Belakang}

Setiap orangpastimemilikiharapanataucita-cita. Sebagai anak-anak, membayangkan akan menjadi apa saat dewasa nanti adalah hal yang menakjubkan. Orangtua pasti menginginkan semua yang terbaik untuk buah hati mereka. Namun, orang tua lupa bahwa anak juga memiliki keinginan, impian dan harapan mereka sendiri. Komunikasi yang buruk antara orangtua dan anak adalah salah satu penyebab terjadinya kasus ini. Mengangkat pokok permasalahan ini, munculah gagasan untuk menjadikan permasalahan ini sebagai kosep utama dalam penciptaan karya. Teknik animasi dua dimensi sengaja digunakan kerena bentuk visual dari animasi 2D memiliki kesan yang ringan namun mudah diingat. Selain itu mempertimbangkan sumberdaya manusia, peralatan yang digunakan serta waktu pengerjaan, teknik animasi 2D adalah teknik yang paling cocok

\section{Rumusan Masalah}

Berdasarkan latar belakang dapat dirumuskan permasalahan sebagai berikut:

1. Permainan yang ada di gadget adalah masalah utama karena jaman sekarang game digital sangat gampang untuk dimainkan

2. Permainan edukasi dalam media permainan kartu di Indonesia masih sedikit dan kurang diminati.

\section{Tujuan dan Manfaat}

Tujuan dari penciptaan karya cardgame “Jungle Quest” ini adalah untuk memberikan hiburan untuk pemainnya, serta untuk membangkitkan era Cardgame ke kalangan masyarakat modern yang cenderung lebih memilih gadget sebagai media bermain. Manfaatnya bagi orang adalah untuk memberikan pilihan permainan dari banyaknya jenis permainan papan di Indonesia.

\section{Target Audien}

Target audien menurut demografis game ini adalah ;
1. Usia
: 10 tahun keatas

2. Jenis kelamin : Laki-laki dan perempuan

3. Pendidikan : Dari latar pendidikan apapun

4. Status sosial : Semua kalangan

5. Negara : Indonesia

6. Bahasa : : Indonesia 


\section{Indikator Capaian Akhir}

Capaian akhir yang akan dicapai adalah suatu produk Cardgame dengan dimensi kartu $12 \mathrm{~cm}$ x $7 \mathrm{~cm}$ dan berjumlah 35 buah.

a. Desain Game

Game “Jungle Quest” merupakan game kartu atau Cardgame yang memiliki cara bermain yang simple tergantung pemainnya. Namun ide utama game ini adalah pemain berlomba mengumpulkan 6 dari 7 kartu hewan. Di awal permainan semua kartu akan di kocok kemudian setiap pemain akan mendapat 6 kartu, sisa kartu akan disebar rapi secara tertutup. Setiap giliran pemain akan mengambil 1 kartu yang sudah di sebar tadi dan membuang 1 kartu kembali ke kumpulan kartu yang disebar secara tertutup juga. Pemenang game ini adalah pemain pertama yang mengumpulkan 6 jenis kartu dari 1 hewan. Permainan berakhir ketika salah satu pemain menang. Pemain yang kalah adalah pemain yang paling sedikit megumpulkan kartu dari 1 jenis hewan.

\section{b. Desain Kartu}

Desain kartu berbentuk persegi panjang dengan ukuran $12 \mathrm{~cm} \mathrm{x} 7 \mathrm{~cm}$, bagian depan kartu berisi nama hewan dan salah satu info dari tujuh info tentang hewan tersebut, ilustrasi dari info, dan bingkai yang menyesuaikan karakter hewan tersebut. Bagian belakang kartu berisi nama permainan dengan background bertema hutan.

c. Tata cara bermain

Tata cara bermain atau biasnya disebut Game Rule adalah hal yang penting di dalam permainan papan, karena dengan adanya petunjuk ini, para pemain jadi mengerti cara bermain dan aturan gamenya secara detail.

\section{LANDASAN TEORI}

\section{Game}

Kata game pada dasarnya berasal dari Bahasa inggris yang berarti permainan. Permainan adalah sesuatu yang digunakan untuk bermain yang dimainkan dengan aturanaturan tertentu. Di dalam permainan ada kondisi menang dan ada kondisi kalah.

\section{Table Top Game}

Tabletop Game adalah istilah yang lebih umum untuk menyebut permainan yang masuk kedalam kategori board game, card game, pencil and paper game, miniature 
game, dice game, dan role playing game. Karena permainan-permainan tersebut lebih lazim dimainkan di atas meja.

\section{Cardgame}

Cardgame adalah bagian dari tabletop game yang di dalamnya terdapat peraturan cara bermain dengan kartu sebagai media utamanya. Genre dalam cardgame ada banyak, yaitu:
a. Trick-taking
b. Matching
c. Comparing
d. Solitaire
e. Drinking Card

\section{PERANCANGAN}

\section{Konsep}

Game "Jungle Quest" dimainkan oleh minimal 3 orang sampai maksimal 5 orang. Di awal permainan semua kartu akan di kocok kemudian setiap pemain akan mendapat 6 kartu, sisa kartu akan disebar rapi secara tertutup. Setiap giliran pemain akanmengambil 1 kartu yang sudah di sebar tadi dan membuang 1 kartu kembali ke kumpulan kartu yang disebar secara tertutup juga. Pemenang game ini adalah pemain pertama yang mengumpulkan 6 jenis kartu dari 1 hewan. Permainan berakhir ketika salah satu pemain menang. Pemain yang kalah adalah pemain yang paling sedikit megumpulkan kartu dari 1 jenis hewan.

\section{Dokumen Konsep}

a. Deskripsi Game

- $\quad$ Abstraksi : Cardgame dengan genre game edukasi . Pemain mendapat informasi mengenai 5 hewan langka Indonesia, sekaligus melatih daya ingat pemain.

- Genre $\quad$ : Game Edukasi

- Tema : Alam Liar

- Visual Style : $\quad$ D

- Pemain : :3-5 pemain

- $\quad$ Player Immersion : Strategy, Memory, Luck 
- $\quad$ Consumer Group $\quad$ : 10 Tahun +

b. Game Technical

- Technical Form : 2D Card

- View : Real Top Down

- Platform : Cardgame

- Control : Hand

- Game Size $\quad: 87 \mathrm{~mm}$ x $67 \mathrm{~mm}$

- Software : : Photoshop CC 2018, Paint tool SAI

c. Komponen game

- Package / Kotak permainan

- Kartu

- Kertas panduan bermain

d. Dimensi Komponen

- Package tutup : $95 \mathrm{~mm}$ x $75 \mathrm{~mm}$ x $20 \mathrm{~mm}$

- $\quad$ Package bawah : $93 \mathrm{~mm} \times 73 \mathrm{~mm} \times 20 \mathrm{~mm}$

- Kartu : $87 \mathrm{~mm} \times 67 \mathrm{~mm}$

- $\quad$ Tata cara bermain $\quad: 87 \mathrm{~mm} \times 134 \mathrm{~mm}$ (dilipat)

\section{Desain Kartu}

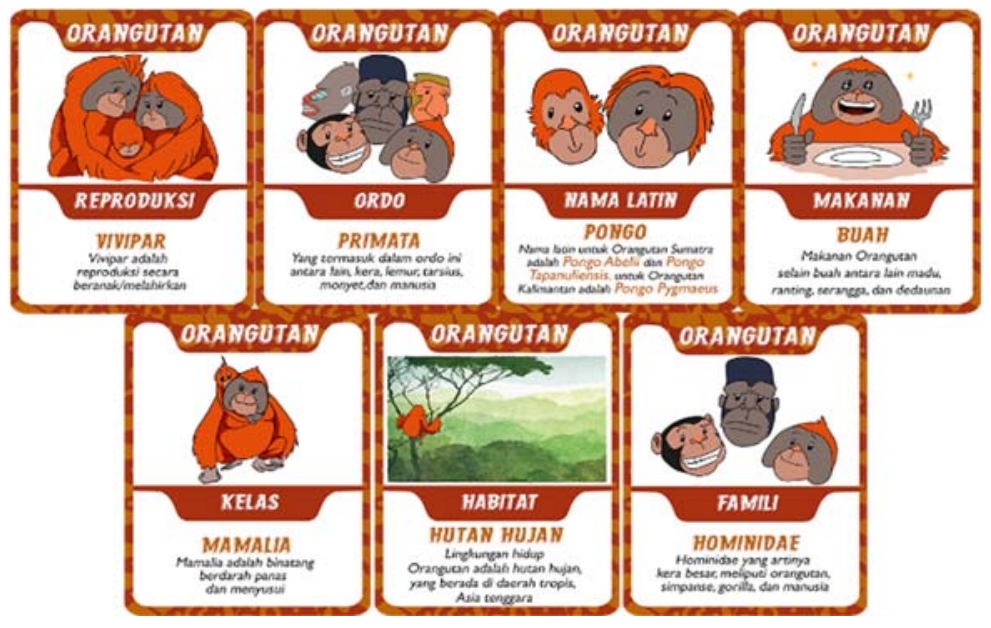

Gambar 1. Desain Kartu Orangutan 
Hizkia Kurniawijaya Hanz

“Jungle Quest” Edukasi Pengetahuan Umum Lima Binatang Langka Indonesia Dalam Permainan Kartu

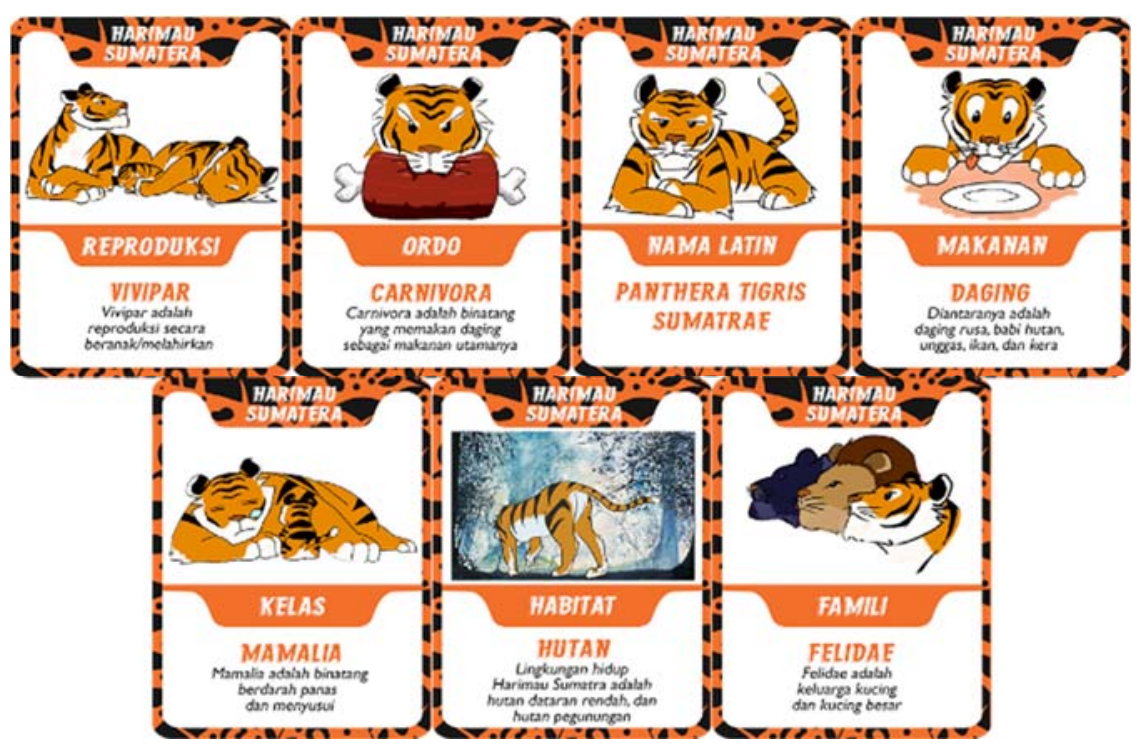

Gambar 2. Desain Kartu Harimau Sumatra

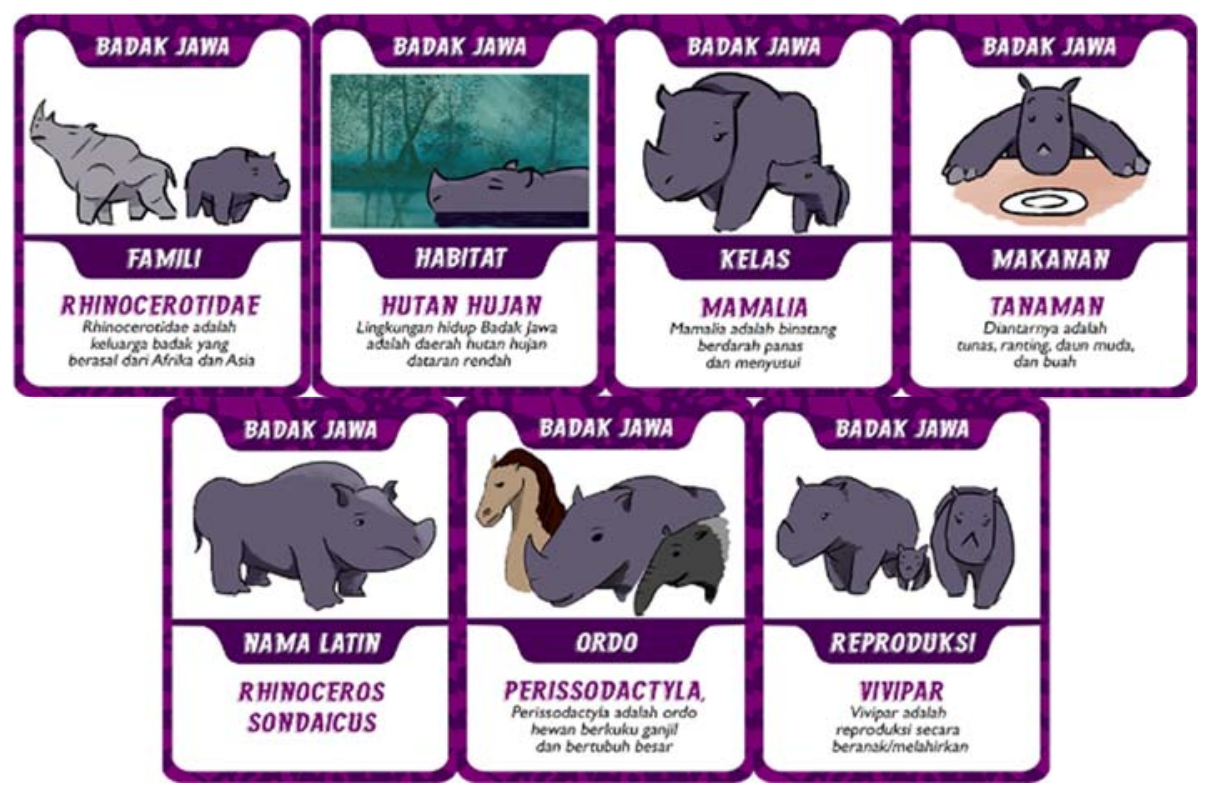

Gambar 3. Desain Kartu Badak Jawa 


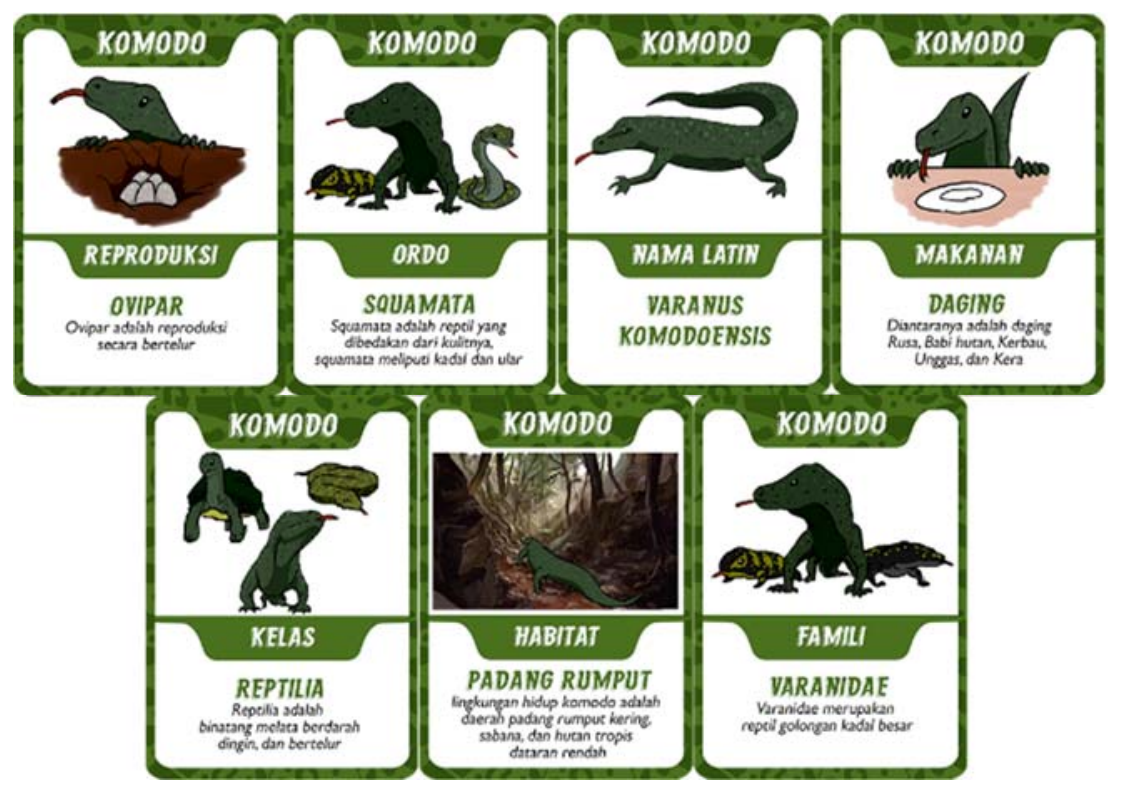

Gambat 4. Desain Kartu Komodo

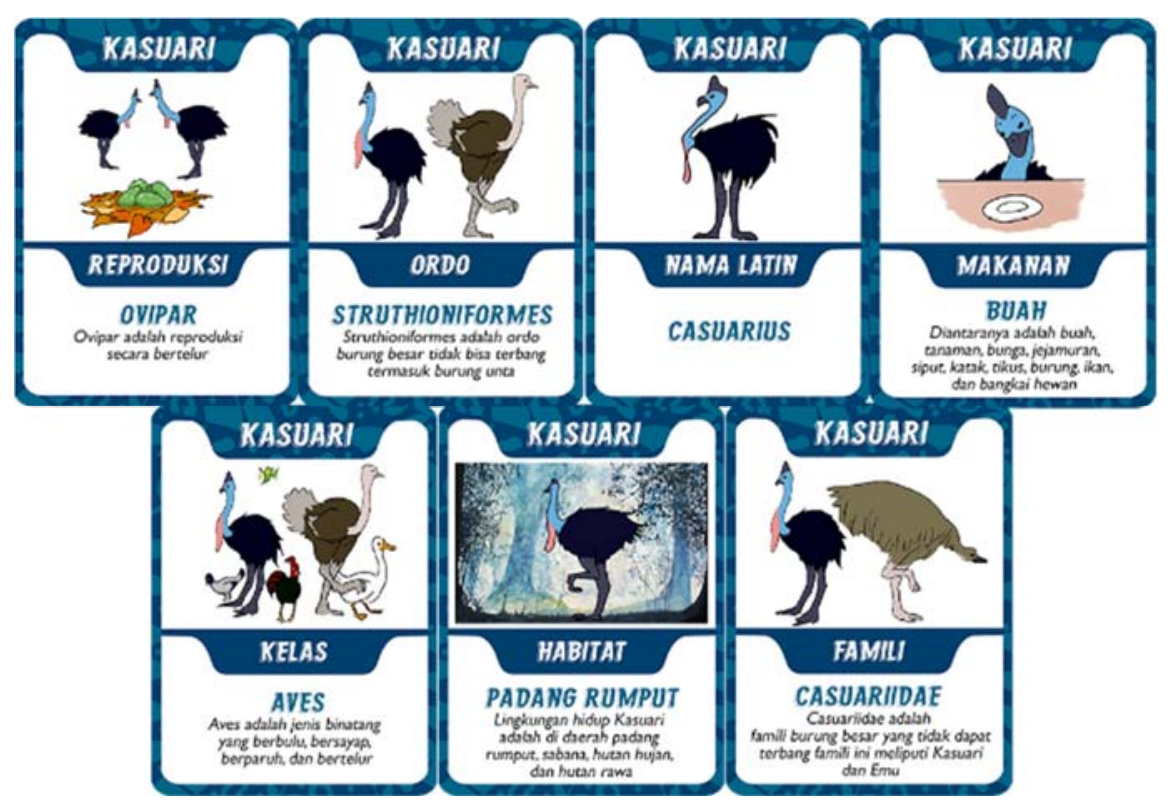

Gambar 5. Desain Kartu Kasuari 
Hizkia Kurniawijaya Hanz

"Jungle Quest” Edukasi Pengetahuan Umum Lima Binatang Langka Indonesia Dalam Permainan Kartu

\section{Desain Backcard}

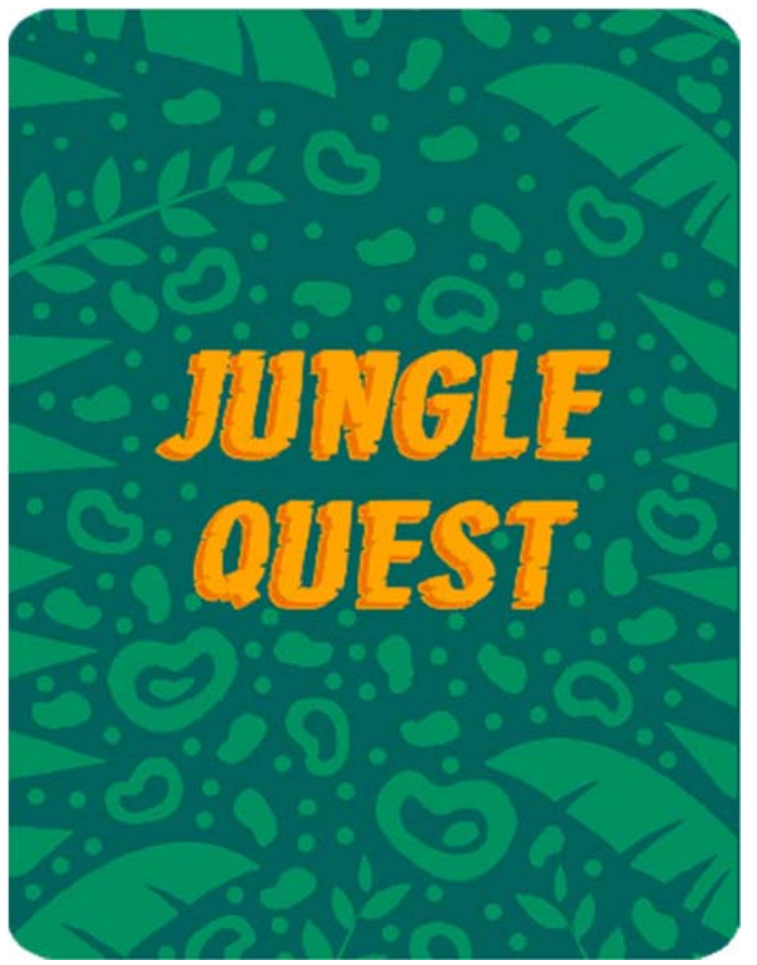

Gambar 6. Desain Backcard

\section{Desain Panduan Permainan}
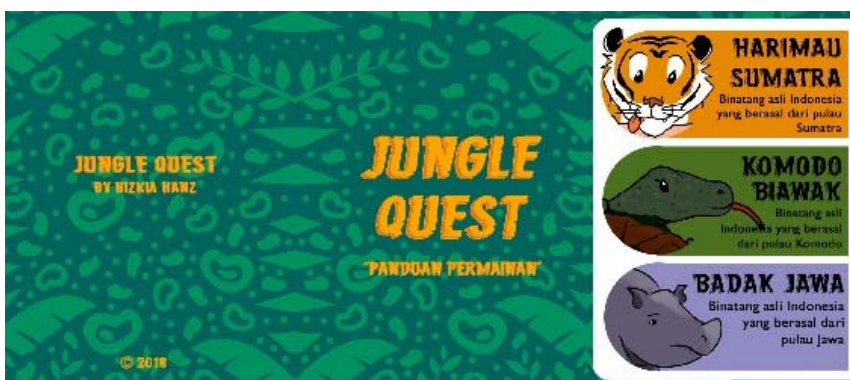

SARAN BERMAIN

1. Pemain berusian 10 cinun ke acas nraksirnal 5 nrang

ang pemain dapat menambah peraturan tii baswah ini:

- Jumlah pemain minimal 3 orang, dan

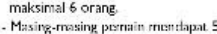
kartu.

- Pemain percama yang mengumpulkan hewan yang berbeda yang, memenanys permainan.
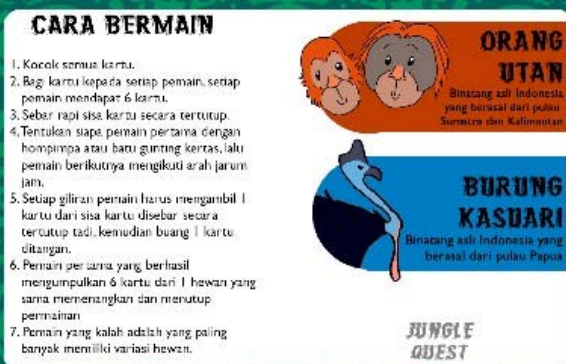

KRITERIA MENANG

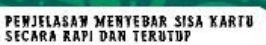

1. Kocalk sermuz karta

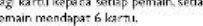

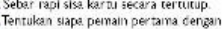

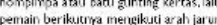

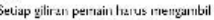
vitanyan.

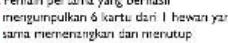

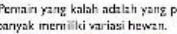

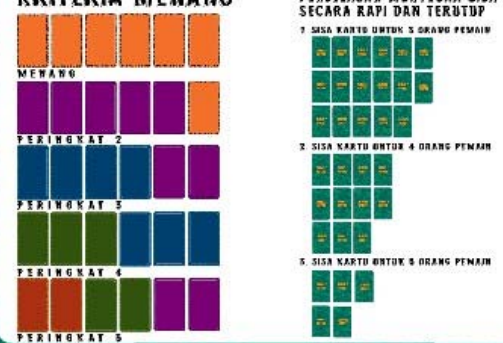

Gambar 7. Desain Panduan Permainan 


\section{Desain Packaging}
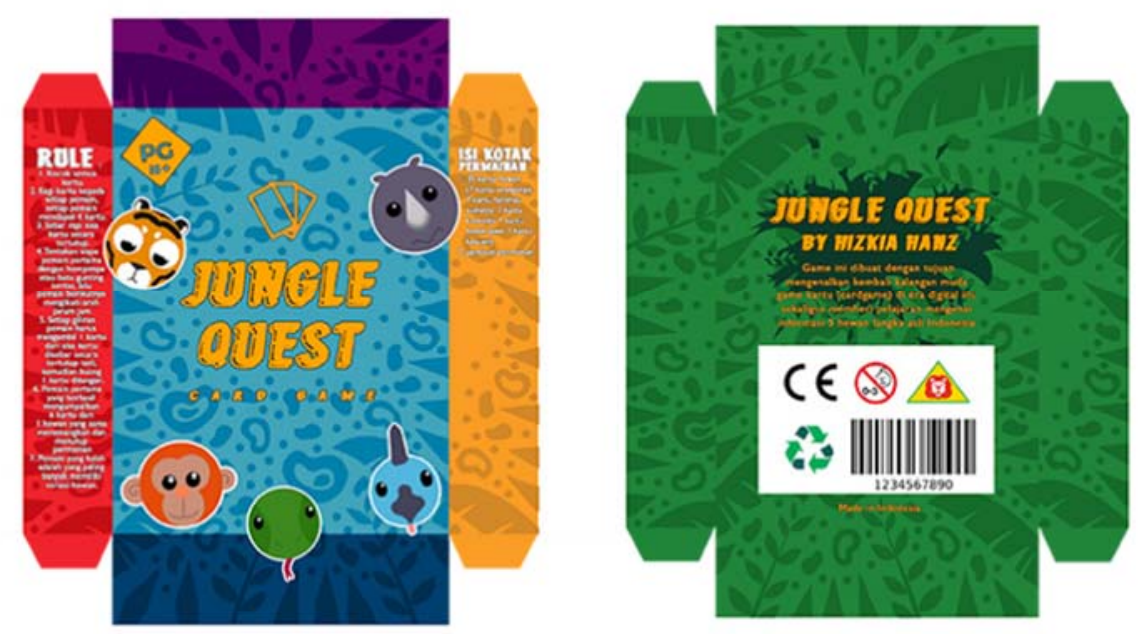

Gambar 8. Desain Packaging

\section{PERWUJUDAN}

\section{Praproduksi}

Proses praproduksi merupakan tahap awal dari proses produksi, termasuk di dalamnya menentukan konsep permainan, menata layout, dan menyusun aturan-aturan permainan gameplaynya.

a. Konsep

Konsep merupakan bentuk gambaran yang akan diproduksi. Konsep game ini pemain berlomba mengumpulkan 6 kartu dari hewan yang sama.

\section{b. Layout}

Layout merupakan tahapan menyusun alur permainan atau biasa disebut prototype awal. Layout dibuat dengan tujuan mengetahui bentuk awal dari permainan "Jungle Quest" agar mempermudah pengerjaan di tahap produksi.

\section{c. Game Rule}

Game Rule atau peraturan permainan adalah hal yang sangat penting dalam game karena ini adalah panduan utama pemain yang baru memainkan game ini. Dalam menentukan aturan game ini harus dimulai dari pengenalan setiap komponen sampai alur permainan dari awal sampai akhir. 


\section{d. Flowchart}

Flowchart adalah diagram bermain, yang harus ada di setiap bentuk game. Flowchart juga menentukan alur permainan yang memperjelas peraturan bermain terutama kepada produser atau supervisor. Berikut flowchart "Jungle Quest” :

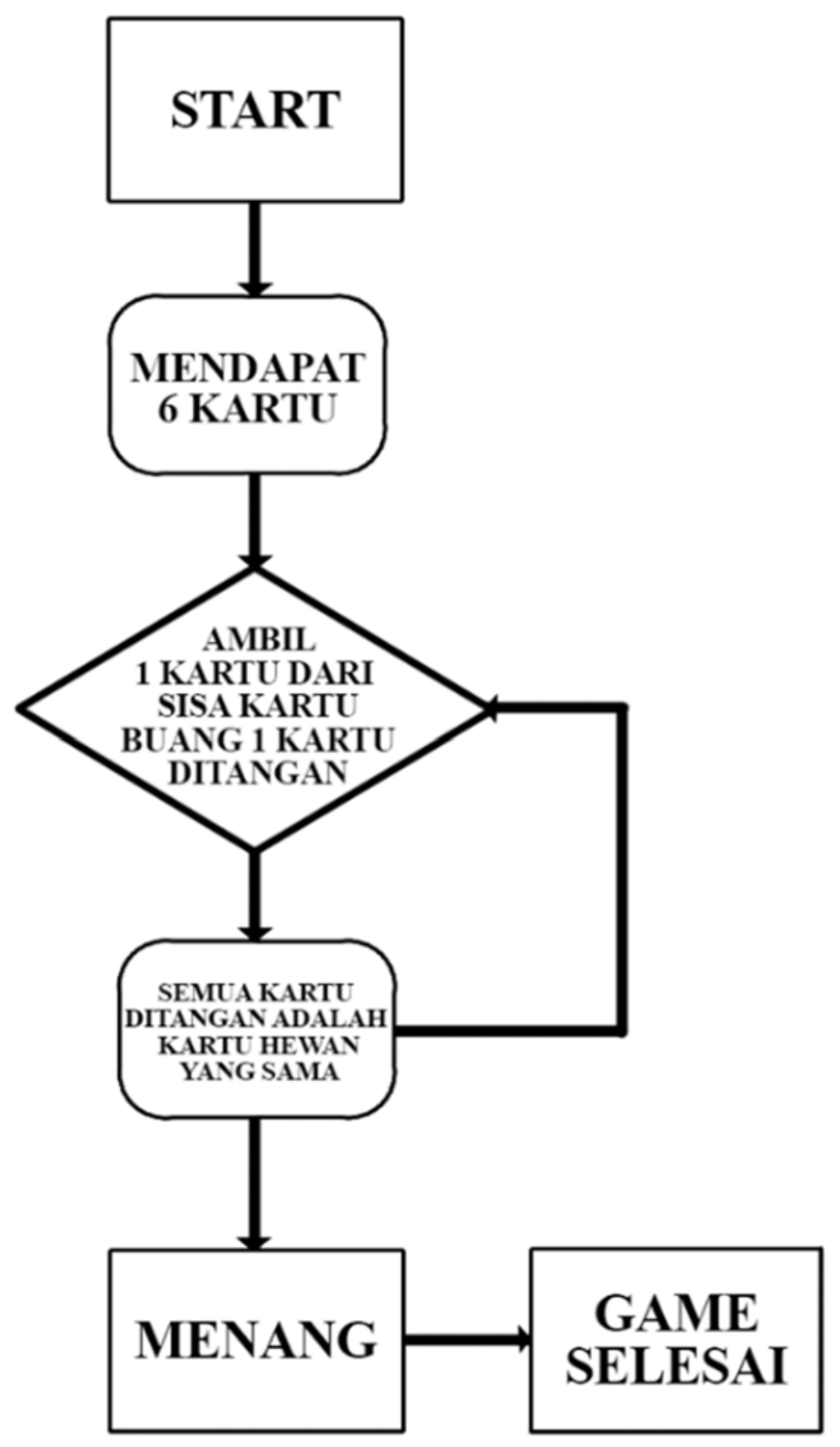

Gambar 8. Flowchart “Jungle Quest” 


\section{Produksi}

a. Desain

Dalam tahap design, semua asset dibuat mulai dari backcard, ilustrasi binatang, frontcard, panduan bermain, dan packaging.

\section{b. Mock Up}

Mock - Up adalah tahapan pembuatan bentuk permainan secara asli namun dengan minim asset atau tanpa design yang jadi di dalamnya, terdapat bentuk layout dan komponenkomponen gamenya, tujuan pembuatan mock-up adalah untuk mengetahui alur permainan ketika sudah jadi nanti, dan menguji kekurangan dan kelebihan game yang sudah dibuat.

\section{c. Alpha Testing}

Alpha Testing adalah tahapan dimana kita sebagai developer game mengumpulkan beberapa game tester atau orang untuk memainkan prototype game kita, tugas mereka adalah memainkan game kita dengan peraturan yang sudah kita buat. Tahap ini membantu developer game untuk mencari kelemahan dan kelebihan game secara langsung.

\section{Pascaproduksi}

a. Final Render

Final Render adalah hasil akhir semua design yang telah dibuat dan siap dicetak dan dikemas di dalam kemasan cardgame “ Jungle Quest “.

\section{b. Packaging}

Setelah semua komponen tercetak, tahap berikutnya adalah pengemasan produk. Produk dikemas serapi mungkin dan terlihat menjual baik dari segi design ataupun tampilan kotaknya.

\section{c. Public Testing}

Public testing adalah tahap dimana kita menyediakan tempat untuk orang memainkan game kita seutuhnya atau dalam keadaan sudah jadi. Public testing dilakukan hanya menggunakan produk kita dalam skala kecil, tujuannya adalah untuk melihat kembali kekurangan dan kelebihan game kita setelah rilis. Setelah ditemukannya kekurangan baru yang tidak terfilter di alpha testing barulah pada tahap berikutnya yaitu tahap massive production atau cetak masal kita bisa 100\% memberikan game kita tanpa ada kendala lagi. 
d. Promo

Promo adalah hal yang sangat penting dalam dunia cardgame, karena tanpa promo, game kita tidak akan dikenal oleh masyarakat, misalkan promo yang kita berikan berupa sebuah video cara bermain dan gameplay. Kita bisa mempromokan video melalui media social, promo lainnya adalah berupa post-post diforum-forum game dalam negeri dan luar negeri.

\section{PEMBAHASAN}

\section{Elemen Formal}

Penciptaan cardgame “Jungle Quest” juga memasukan beberapa unsur-unsur dari cardgame itu sendiri, di jelaskan sebagai berikut :

\section{a. Prosedur}

Game "Jungle Quest" berakhir jika salah satu pemain berhasil mengumpulkan 6 kartu dari satu hewan. Setiap putaran, pemain diberi kesempatan untuk membuka kartu baru dari sisa kartu yang disebar tertutup untuk mendapatkan kartu baru dan membuang kartu yang tidak diinginkan agar pemain lain mendapat kesempatan yang sama.

b. Aturan

1. Game dimainkan oleh 3 sampai 5 orang dengan bersifat individu

2. Semua kartu akan dikocok se-acak mungkin, kemudian setiap pemain masingmasing mendapat 6 kartu.

3. Sisa kartu akan di sebar secara rapi dan tertutup

4. Game dimulai dengan undian Gunting, Batu, Kertas atau hompimpa untuk menentukan pemain pertama di permainan pertama, atau pemenang game sebelumnya untuk permainan kedua dan seterusnya.

5. Setiap giliran pemain mengambil 1 kartu dari sisa kartu yang tertutup, kemudian membuang 1 kartu yang tidak diinginkan ditangan.

6. Pemenangnya adalah pemain yang pertama mengumpulkan 6 kartu dari satu hewan yang sama.

7. Permainan berakhir ketika salah satu pemain menang, dan semua pemain harus menunjukan kartu ditangan masing-masing.

8. Pemain yang kalah adalah pemain dengan kartu ditangan paling bervariasi. 


\section{KESIMPULAN}

Pembahasan seluruh materi pada bab I sampai dengan bab V, dapat diambil kesimpulan bahwa :

1. Kualitas sebuah game ditentukan oleh grafis, gameplay, dan cerita / roleplay;

2. Tahap-tahap pembuatan game terdiri dari menentukan ide, konsep permainan, menyusun peraturan bermain, memulai perancangan desain, membuat prototype atau mock-up, melakukan play test, finishing, dan packaging;

3. Pembuatan game “Jungle Quest" dirancang dengan konsep game yang cukup kompleks tapi dapat dimengerti oleh banyak orang, karena tetap memberikan elemen-elemen dasar berdasarkan game-game yang sudah ada sebelum "Jungle Quest" muncul;

4. "Jungle Quest" adalah game yang mampu menghibur kelompok bermain antara teman ataupun orang tua dengan anak.

\section{SARAN}

Beberapa saran yang didapat dari penelitian ini adalah :

1. Memberikan tambahan kartu efek seperti dalam permainan UNO untuk menambah ketegangan pemain.

2. Meningkatkan kualitas produksi, untuk mengembangkan daerah jual menjadi internasional. 


\section{DAFTAR PUSTAKA}

\section{Buku Elektronik :}

Dublin Gazette (1750). The Dublin Gazette (Number 26). Dublin: Richard James and John Butler, 1750.

Dummett, Michael; Abu-Deeb, Kamal (1973), "Some remarks on Mamluk playing cards", Journal of the Warburg and Courtauld Institutes, 63: 106-128

Lo, Andrew (2000), "The Game of Leaves: An Inquiry into the origin of Chinese playing cards", Bulletin of the School of Oriental and African Studies, University of London, 63: 389-406

Parlett, David (1990), The Oxford guide to card games: a historical survey, Oxford University Press

Temple, Robert K.G. (2007). The Genius of China: 3,000 Years of Science, Discovery, and Invention (3rd edition). London: André Deutsch, pp. 130-131

\section{Laman:}

https://www.britannica.com/topic/card-game, diakses pada tanggal 4 Desember 2018 pukul 11.24 WIB.

http://jducoeur.org/game-hist/game-rules.html, diakses pada tanggal 4 Desember 2018 pukul 11.30 WIB.

https://www.i-p-c-s.org/history.html, diakses pada tanggal 4 Desember 2018 pukul 11.24 WIB.

http://www.parlettgames.uk/histocs/ diakses pada tanggal 4 Desember 2018 pukul 12.15 WIB. 